\title{
Multiespacialidades metropolitanas e construção social do lugar - rumos para a sustentabilidade
}

\section{Metropolitan multispecialities and social constrution - sustainability ways}

Cristina de Araújo LIMA ${ }^{1}$

\begin{abstract}
RESUMO
A Região Metropolitana de Curitiba - $\mathrm{RMC}^{2}$ - é constituída de espacialidades diferenciadas e, ao mesmo tempo em que sedia atualmente o terceiro maior pólo industrial automobilístico do país, é a única região metropolitana brasileira em que houve crescimento demográfico tanto do pólo, Curitiba, quanto da periferia imediata superiores à taxa de crescimento da população brasileira. Entre 1970 e 2000, Curitiba apresentou a maior taxa geométrica de crescimento anual, $2,13 \%$ no pólo e $4,86 \%$ a.a. na periferia. (IBGE, 2000). Contudo, na periferia metropolitana, onde se concentra $90 \%$ da população da RMC, as condições sociais e de infra-estrutura urbana são precárias. $12,46 \%$ dos domicílios têm chefes de família com renda de até 1 salário mínimo, ou aproximadamente US\$ 80,00 por mês, o que justifica a existência de locais com favelas e sub-habitações na cidade. No entanto, essa proporção sobe para $50 \%$ ou mais nos municípios vizinhos. Enquanto em Curitiba o montante populacional triplicou em apenas 20 anos, no restante da região metropolitana o incremento populacional foi muito reduzido. No debate acerca dos rumos de uma sustentabilidade metropolitana, busca-se compreender a dimensão ambiental como o todo de inter-relações socioambientais, analisando-se as condições da população do primeiro patamar de adensamento urbano no qual se entende que um reforço ao sentido de lugar seria pressuposto para uma maior sustentabilidade.

Palavras-chave: região metropolitana, urbanização, sustentabilidade urbana.
\end{abstract}

1 Arquiteta, doutora em Meio Ambiente e Desenvolvimento (UFPR, 2000); professora e coordenadora do Curso de Arquitetura e Urbanismo da UFPR; professora e coordenadora do Curso de Especialização "Cidade, Meio Ambiente e Políticas Públicas - Departamento de Arquitetura e Urbanismo UFPR"; professora do Programa de Mestrado em Construção Civil - UFPR; professora do Programa de Doutorado em Meio Ambiente e Desenvolvimento - UFPR.

2 A Região Metropolitana de Curitiba - RMC, foi criada por lei federal em 1973. 
LIMA, C. de A. Multiespacialidades metropolitanas e construção social do lugar...

\begin{abstract}
The metropolitan region of Curitiba - MRC - contains several spatial configurations and, besides having the third automobile industry of the country; it is currently the only metropolitan region with a population growth rate higher than the national average. Between 1970 and 2000, it had the highest geometric growth rate among metropolitan regions in Brazil: it grew $2.13 \%$ in its core and $4.18 \%$ in the suburbs (IBGE, 2000). However, last places are where $90 \%$ of the population live. There, social and urban structures are underdeveloped and the population number has risen three times in the last twenty years. Whereas in Curitiba $12.46 \%$ of the houses have an income around US $\$ 80$ per month, in the suburbs this proportion rises to $50 \%$ or more. Discussing sustainability, it is necessary to understand the environmental dimension as a social and natural whole. In this paper analyze some aspects of the population conditions in the nearest neighborhood of Curitiba, where an improvement of the locus sense of place could contribute to a metropolitan and urban sustainability.

Key-words: metropolitan region, urbanization, urban sustainability
\end{abstract}

\section{Introdução}

O impulso dos anos setenta nas modificações socioeconômicas do processo de internacionalização da economia repercutiu também no contexto da Região Metropolitana de Curitiba e, assim como outros nós de interligação com centros mundiais de negócios, pólos regionais passaram a se constituir em "ilhas de prosperidade". No caso em questão, observa-se que ao redor da capital curitibana se conformou um locus logisticamente interessante para localização de empresas de médio e grande porte em meio à existência de espacialidades urbanas bastante diferenciadas. Atualmente, a par do destaque do pólo industrial, a região está crescendo no recorte espacial menos privilegiado, a periferia metropolitana, que conta com limitados recursos para se inserir na marcha econômica do pólo. Ao invés de diminuir, há tendências de aumentar a população de sub-habitações tanto de Curitiba quanto do aglomerado urbano contíguo.

Essa situação reverte as perspectivas de êxito das soluções técnicas de urbanismo que funcionaram no pólo, pois se destinam a um ambiente urbano que apresenta outras formas de retorno dos investimentos que não as usuais compensações por atividades de alta produtividade. Assim, fragilizam-se as perspectivas de êxito dos instrumentos ur- banísticos convencionais, pois as demandas se apresentam sem possibilidade de perpetuar o padrão de urbanização tido como modelo. Considera-se portanto, que há que se tornar a cidade legal e tecnicamente organizada acessível à população de mais baixa renda, que atualmente cresce mais que o pólo organizado e cada vez mais se abriga nas ocupações marginais, precárias ou ilegais. Isso requer soluções técnicas inovadoras, além de disposições legais e políticas direcionadas para um cenário urbano que seja física e socialmente não excludente. Isso seria avançar para uma maior sustentabilidade.

\section{Sustentabilidade}

Havendo uma cidade-pólo metropolitana que apresenta adequadas condições de urbanização ${ }^{3}$ desenvolvidas com o detalhamento de seu Plano Diretor, desde a década de setenta, e, portanto, considerando-se esse espaço como detentor de situações indicativas de sustentabilidade urbana, passa-se a pensar sobre como seria possível otimizar, prolongar essa condição, e mesmo expandir seu contexto de aplicação para todo o aglomerado urbano metropolitano, o Primeiro Patamar de Adensamento Metropolitano da Região Metropolitana de Curitiba aqui focalizado. ${ }^{4}$

\footnotetext{
3 Referência à cidade de Curitiba e sua trajetória de planejamento urbano, sendo destaque algumas iniciativas e programas como o de separação de lixo "Lixo que não é lixo"; o sistema de transporte urbano; o instrumento de troca de potencial construtivo por áreas de preservação ambiental e outros. Ver IPPUC. Curitiba - uma experiência de planejamento. Curitiba, 1996. Em relação à leitura das práticas de Curitiba por estrangeiros, toma-se por base: CAMPANA, F. Curitiba pelos ingleses. Curitiba, Gazeta do Povo, jul. 2004, p. 8.

4 No artigo é utilizada a expressão 'Primeiro Patamar de Adensamento Metropolitano' para a área composta pelos municípios de Curitiba e seus vizinhos imediatos: Araucária, Campo Largo, Campo Magro, Almirante Tamandaré, Colombo, Campina Grande do Sul, Quatro Barras, Pinhais, Piraquara, São José dos Pinhais e Fazenda Rio Grande.
} 
LIMA, C. de A. Multiespacialidades metropolitanas e construção social do lugar...

Inicialmente, para pensar a sustentabilidade no contexto a que se propõe este artigo, considera-se necessário estabelecer algumas premissas básicas:

- o ambiente urbano comolocus central de um processo de urbanização do mundo;

- tornar viável o desenvolvimento urbano com qualidade ambiental;

- a sustentabilidade como um conjunto de condições que pode ser objeto de uma trajetória continuada e crescente de aperfeiçoamento, ampliação e fortalecimento;

- a sustentabilidade em seu conceito ampliado que envolve condições de vida no contexto físicobiológico e também socioeconômico e cultural.
- que o planejamento urbano ambiental é ferra-menta útil para a construção da sustentabilidade urbana, dentre outros recursos de diversas modalidades.

Sendo assim, o que se entende aqui por sustentabilidade e, no caso, sustentabilidade urbana?

No conceito referencial de 'desenvolvimento sustentável' apresentado no documento "Nosso futuro comum" 5 dos anos oitenta, entende-se a vinculação desse conceito ao planejamento e gestão continuadas, quer de recursos naturais quer de recursos de outra natureza, em locais, países e instituições com a finalidade de manutenção das condições de qualidade de vida da população nas diferentes gerações. Ou seja, o objetivo do desenvolvimento seria a qualidade de vida sustentável ou duradoura, e do que trata

FIGURA 1 - REGIÃO METROPOLITANADECURITIBA: ESP AÇOS EMANÁLISE. METROPOLITAN AREA OF CURITIBA: SPACESIN ANALYSIS.

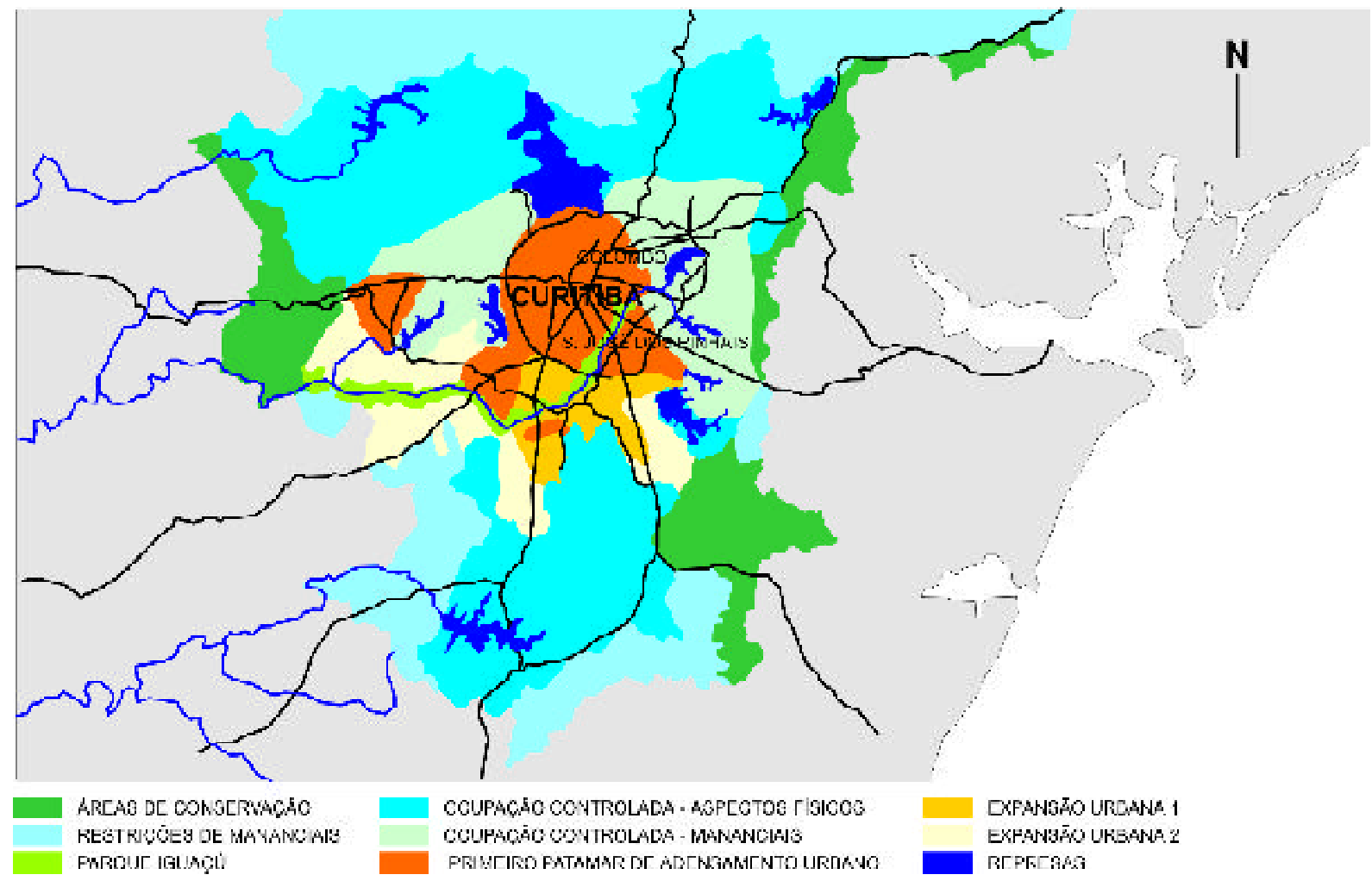

FONTE: COMEC 2003, ORG. LIMA, 2004.

5 Relatório da Comissão Mundial sobre Meio Ambiente e Desenvolvimento das Nações Unidas, publicado em 1987 e conhecido também pelo nome da sua presidente, a ministra norueguesa Gro Harlem Brundtland. 
LIMA, C. de A. Multiespacialidades metropolitanas e construção social do lugar...

isto? Caso se aceite que haja inúmeras e diferentes acepções pessoais para o que sejam 'adequadas condições de vida', pode-se, ao menos, partir de que o atendimento às condições mínimas de sobrevivência sejam condições básicas inquestionáveis: acesso a alimentação, higiene, vestimenta, habitação, trabalho, transporte, educação e saúde, todos os itens com qualidade. Ou seja, a qualidade de vida é uma condição fundamental para a cidadania, a qual deve ser construída por atores sociais conscientes, ou seja, politizados no sentido de ter clareza nas opções e objetivos sociais de aumento da qualidade de vida da coletividade e dos indivíduos. Nessa seqüência de pensamento, pode-se afirmar que a sustentabilidade urbana é uma condição sempre otimizável que visa a oferecer as condições básicas materiais e imateriais para a realização da coletividade nas diferentes gerações. Esse embasamento engloba o conceito de sustentabilidade ampliada e progressiva, como apresentam Bezerra e Fernandes.

Admitindo-se esse entendimento, o contexto urbano, nas dimensões física e social, analisado neste artigo, tem pela frente um longo caminho, pois, de imediato, verificam-se muitas carências: nos serviços públicos básicos como coleta e tratamento de esgoto; educação e saúde; oportunidades de emprego e renda e conseqüente precariedade quanto à aquisição de alimentos e recursos de qualidade, vestimenta, acesso a ensino e materiais para estudo; custos de transporte sendo um item predominante no orçamento, e outros aspectos.

No entanto, há que se considerar que o debate e o aprofundamento de como viabilizar a sustentabilidade urbana é um assunto recente na agenda da administração pública das esferas local, regional ou nacional, e até mesmo de grupos de países diversos que dividem ecossistemas (ecótonos) comuns, como bacias hidrográficas, florestas, porções litorâneas ou marítimas e outras situações. Uma das dificuldades para se entender por onde ir para ampliar as bases de uma sustentabilidade urbana é a fundamentação cartesiana do pensamento técnico que vem se atualizando e passa a envolver a percepção da complexidade. Parece haver diferentes sustentabilidades conforme as características dos subsistemas em questão e, além disso, diferentes temporalidades no processo.

\section{Diferentes sustentabilidades e politicas urbanas}

Buscando os melhores condicionantes para sustentabilidade por meio de políticas urbanas, há que se verificar o teor das ações e resultados propostos e previstos. Qual a melhor política para a sustentabilidade urbana?

De imediato, vem a resposta da esfera físico-biológica. Não há como haver cidade sem os recursos naturais fundamentais, que, por sua vez são resultantes da manutenção da capacidade natural de renovação dos ciclos vitais da água, do oxigênio, da cobertura vegetal e de outros sistemas. $\mathrm{O}$ ambiente artificializado das cidades é dependente dos recursos naturais renováveis e não renováveis. Quão artificial pode ser a cidade, ou seja, quão independente dos ciclos naturais pode ir a sustentabilidade urbana?

Partindo-se do conceito clássico de 'paradigma' como o exemplo que serve de modelo, tem-se o caso dos modelos arquitetônicos, como lembra Wigley(1994). Esãojustamente aos modelos de arquitetura e por extensão, de cidade, que são direcionados os nossos contextos urbanos espontâneos e tradicionais. No entanto, dentro, e especialmente fora ou nos limites dos traçados urbanos legais, no contexto marginal dos aglomerados urbanos contemporâneos, construídos pela urgência da necessidade inadiável de abrigo, nas periferias urbanas, os modelos não têm se encaixado, não por problemas técnicos ou tecnológicos, mas por limitações socioeconômicas, políticas, administrativas que levam a conformar um processo veloz e marcante de degradação ambiental e social. E são, justamente, a partir dessas limitações delineadas pela conjuntura socioeconômica e política que pode-se localizar o ponto de inflexão, o cerne da resposta para reverter para um quadro que favoreça o desenvolvimento mais sustentável-tanto na dimensão físico-ambiental como também na dimensão sociocultural.

A sustentabilidade urbana é conformada pelo todo do contexto físico-biológico e pelo contexto socioeconômico e cultural. Já há tempo que a insustentabilidade urbana, retratada pelo processo de degradação socioambiental - bem nítido em bairros pobres e periferias das grandes cidades - percorre trajetórias próprias a cada meio, sociedade, cultura, pelo mundo afora. ${ }^{6} \mathrm{O}$ conceito de

6 Referência a problemas de mercado de trabalho dos países em geral, inclusive dos países centrais, que levam a níveis insustentáveis de vida, conforme Relatório das Nações Unidas. Atualmente, $25 \%$ dos 35 milhões de desempregados nos países desenvolvidos estão sem emprego há mais de dois anos. Segundo Rattner, no Reino Unido, $30 \%$ da população economicamente ativa foi excluída das oportunidades de trabalho, outros $30 \%$ sobrevivem de trabalhos temporários ou precários, enquanto apenas $40 \%$ continuam em trabalho regular, sem garantia de permanência (RATTNER, 2001). 
sustentabilidade vem sendo moldado aos poucos e ainda permanece como conteúdo em elaboração. No entanto, o embasamento social parece revigorar-se cada vez mais como fundamento e estrutura para o comportamento ambiental consciente. Pode-se reconhecer uma espécie de 'raiz primaz' do conceito de sustentabilidade no vigor da crítica aos processos de apropriação da natureza instaurados pela Revolução Industrial e, também, e especialmente, pelo contexto degradante da conjuntura social que se conformou com os novos modos de produção surgidos naquele período. São as bases do pensamento ambientalista, originadas no século XIX, que se desdobraram em higienismo, naturismo e no conservadorismo, cada qual apresentando conotações variadas (PIERRI, 2001). Dessas vertentes brota a sustentabilidade como conceito moldado pelo debate das sociedades, permitindo leituras diferenciadas graças a compreensões e interesses diferenciados do seu significado e aplicação. Acselrad (1999) apresenta diferentes matrizes discursivas da sustentabilidade urbana, e conclui que

ao promover uma articulação 'ambiental' do urbano, o discurso da sustentabilidade das cidades atualiza o embate entre 'tecnificação' e politização do espaço, incorporando, desta feita, ante a consideração da temporalidade das práticas urbanas, o confronto entre representações tecnicistas e politizadoras do tempo, no interior do qual podem conviver, ao mesmo tempo, projetos voltados à simples reprodução das estruturas existentes ou a estratégias que cultivem na cidade o espaço por excelência da invenção de direitos e inovações sociais.

No contexto de países como o Brasil, considerado pólo de poder emergente, ${ }^{7}$ considera-se adequado pensar a 'sustentabilidade ampliada' como conceito "que trabalha a sinergia entre as dimensões ambiental, social e econômica do desenvolvimento" e, também, do ponto de vista de processo, a 'sustentabilidade progressiva' como conceito que trabalha a sustentabilidade como um desenrolar pragmático do desenvolvimento sustentável (BEZERRA; FERNANDES, 2000). Considerando o vasto território e as diferenças regionais e sociais do país, as trajetórias das práticas técnico-políticas e sociais que forem realizadas é que vão definir, aos poucos, e diferentemente para cada local, o quadro de sustentabilidade urbana que pode ser composto. Nessa linha de pensamento, reforça-se a importância da consciência política e social dos cidadãos.

Cidade ecológica seria então a cidade que busca a sustentabilidade como meta progressiva e continuada como prioridade absoluta. Para Register (1987), uma cidade ecológica é uma cidade saudável que ainda não existe no todo; existem partes de cidade ecológica nas cidades atuais e em algumas ao longo da história. O conceito de cidade ecológica está surgindo em mosaico. Existiriam traços de cidades ecológicas nas antigas cidades européias e aldeias indígenas norte-americanos do sudoeste. Suas características comuns eram ser compactas, ocupar pouco espaço e gastar pouca energia. Esse tipo de assentamento modificava lentamente a natureza original, utilizava poucos materiais, e mesclava-se à paisagem, além de integrar-se aos ritmos biológicos da natureza. No entanto, várias dessas cidades exauriram seus recursos, derrubando florestas para lenha, ou contaminaram gravemente rios e córregos com excrementos humanos e de animais. Segundo esse autor, as cidades ecológicas poderiam substituir as cidades atuais, que seguem um modelo de crescimento que gera muito desperdício de recursos e ocupa grandes extensões de área.

Acredita-se que a cidade ecológica seria constituída a partir da revisão de procedimentos na relação homemnatureza, ou seja, pelo trabalho. Seria a substituição de padrões de consumo da natureza, o que é possibilitado pela reflexão sobre os impactos dos processos tradicionais e pela pesquisa de alternativas de produção, tendo-se em vista o suporte estrutural, econômico e social das comunidades. Consumo tem relação com a existência de recursos materiais, meios técnicos e tecnológicos para apropriação de um bem e suporte econômico e social para a viabilização da forma de consumo.

Também, para se concretizar uma cidade ecológica serianecessária uma mudança depadrão de crescimento, desfazer as grandes concentrações urbanas em localidades menores, principalmente para que a população local tome a si a responsabilidade pelo seu crescimento populacional e pelas opções tecnológicas e comportamentais para a sustentabilidade em seu sentido amplo, procurando estabilizar ou diminuir a geração de impactos negativos no meio ambiente.

\footnotetext{
7 Com enormes potencialidades naturais e humanas, o Brasil tem pela frente um desafio de consolidar a nação, principalmente frente à redefinição do papel dos territórios nacionais no contexto global, em que desponta como detentor dos maiores estoques naturais de água doce e de biodiversidade do planeta (EGLER,C. 2002, p 46). Ao mesmo tempo, as estatísticas oficiais revelam a perda de 2 milhões de empregos nos ramos da indústria e serviços desde 1988 , quando foi instaurada a política estrutural do ajuste econômico fomentada por agências financeiras multilaterais (RATTNER, 2001)
} 
LIMA, C. de A. Multiespacialidades metropolitanas e construção social do lugar...

Sendo as bases da sustentabilidade fundadas nas relações do trabalho (homem-natureza) com suas implicações sociais, econômicas e políticas, então os procedimentos técnico-políticos do planejamento das características da rede urbana - infra-estrutura, serviços e equipamentos urbanos - estariam condicionados não só pela dimensão ambiental mas pela rede de relações de poder que os assentamentos urbanos retratam. A insustentabilidade urbana estaria distante da realidade urbana tanto quanto os procedimentostécnico-administrativos:

Sistemas de planejamento fundados em instrumentos de gestão estáticos, que consideram apenas aspectos espaciais e não assimilam processos sociais e econômicos, têm produzido disfunções no crescimento das cidades e têm se mostrado distantes da realidade urbana. Tais disfunções se manifestam negativamente no plano da cidadania, nos aspectos econômicos, sociais e físicoterritoriais, tornando ineficazes os instrumentos de gestão como orientadores do desenvolvimento urbano. Os problemas relacionados ao uso e à ocupação do solo têm se constituído no principal desafio para a gestão de cidades e metrópoles. Grande parte da população vive em assentamentos à margem das normas. (IPEA, 2002, p. 281)

Acredita-se que análises das condições de vida do contexto socioespacial possam contribuir para formatar um quadro referencial de subsidio às ações públicas voltadas à sustentabilidade urbana.

\section{Condições de vida no primeiro patamar de adensamento metropolitano}

Na medida em que o ser humano passou a ter maior domínio sobre as condicionantes materiais e imateriais do seu cotidiano, em relação às condições de vida, passou a poder planejar alguns resultados. Assim evoluíram variadas formas de planejamento, inclusive a atividade profissional de planejamento urbano, que se vincula e busca configurações físicas para subsidiar e ampliar a qualidade de vida de uma dada sociedade. ${ }^{8} \mathrm{O}$ planejamento urbano se mantém em uso e se justifica para estruturação material das relações sociais, atividades produtivas já apropriadas pela conformação social de cada contexto histórico, político, tecnológico, cultural. O planejamento urbano, como provimento antecipado da produção da base física para as atividades humanas, ${ }^{9}$ não consegue, de forma isolada, assegurar a concretização de alguma atividade humana. É a sociedade que produz o espaço a partir da intervenção peculiar do trabalho, individual ou coletivo, sendo trabalho entendido aqui como a forma d e o ser humano se relacionar e transformar o mundo. ${ }^{10}$ Esta mesma sociedade que habilita os espaços humanos, compartilha estes espaços comas indústrias, as empresas públicas ou privadas que são instituições que estabelecem rotinas de trabalho e produtos para os mais variados fins. Enfim, há uma sociedade que sustenta financeira e politicamente as propostas de planejamento urbano; éa essa sociedade que as propostas se destinam e é ela a razão da sua existência.

Considerando-se que o aglomerado urbano metropolitano, aqui denominado 'Primeiro patamar de adensamento', da Região Metropolitana de Curitiba seja a base socioeconômica e cultural de uma centralidade urbana de bases sustentáveis polarizada por Curitiba (e aceitando-se que tal conceito seja válido e viável para uma construção coletiva), entende-se como fundamental o conhecimento das características de quem produz o espaço, a população, a fim de se buscar otimizar o planejamento urbano e a ação resultante deste, e implicitamente o uso de recursos naturais, materiais e humanos.

8 Entende-se a formatação do conceito de qualidade de vida como a satisfação do indivíduo quanto a valores individuais e societários; tanto materiais (recursos econômicos, condições de habitação, emprego, saúde e educação) quanto os recursos e valores imateriais, como aqueles vinculados a ideologia, política, relacionamento humano e relações de trabalho, cultura, religião, etc.

9 Em bases epistemológicas, pode-se dizer que os aspectos dinâmicos e instáveis da realidade reconfiguram continuamente as matrizes do planejamento urbano, levando às práticas técnicas de menor espaço de tempo, na busca por corresponder às solicitações dos usuários, ou para atender a uma leitura e interpretação técnica do espaço, feita a partir de frames de um quadro real. Assim, a epistemologia pode analisar criticamente compatibilidades e incompatibilidades de um método científico, porém, no contexto das transmutações urbanas velozes, os procedimentos técnicos ainda carecem de abordagens em tempo real.

10 Referência ao entendimento de que não basta haver o espaço físico de qualidade para que se assegure um uso de qualidade nele; não basta construir a sala de aula sem haver um sistema de ensino de boa qualidade para se assegurar bons resultados além da sustentação econômica e política para destinar recursos e especificar prioridades; não basta construir um sistema viário bem projetado se não houver condições de a sociedade adquirir e manter os veículos, pagar pelo de transporte coletivo, etc. 
LIMA, C. de A. Multiespacialidades metropolitanas e construção social do lugar...

Primeira fase da busca de indícios: crescimento populacional, renda, produto interno bruto

Analisando-se a taxa de crescimento populacional dos 12 municípios do aqui denominado "Primeiro Patamar de Adensamento" da Região Metropolitana de Curitiba no período 1991 a 2000 em relação às taxas de crescimento populacional da cidade-pólo, do restante da região, das regiões metropolitanas nacionais e do país como um todo, verifica-se que Curitiba tende a diminuir seu ritmo de crescimento, tendo ficado com 2,13\% a.a., mais próxima da taxa de crescimento apresentada pelas demais regiões metropolitanas brasileiras no mesmo período, que foi de 2,30\% a.a. Os dados revelam que os demais municípios do Patamar cresceram 2/3 mais que a sua cidade-pólo. Verifica-se que, do conjunto de 12 municípios, ou seja, 16,66\% apenas - Curitiba e Campo Largo - apresentam crescimento inferior a 3,0 \% a.a. A metade dos municípios cresceu a taxas entre $3,6 \%$ até $5,6 \%$ e os quatro restantes estão crescendo muito - entre $6,82 \%$ a $9,05 \%$ a.a.

É interessante observar que ao compararem-se as taxas de crescimento populacional com renda e PIB, verifica-se que Curitiba tem 1/3 do crescimento populacional do seu entorno, mas apresenta o dobro da renda do segundo município, em uma escala decrescente. No entanto, a renda média em Curitiba não passa de 2,4 salários mínimos, ou seja, lidera seguida pela média dos três municípios de maiorrenda (1,15 salário mínimo) - São José dos Pinhais, o terceiro pólo automotivo brasileiro, Pinhais e Quatro Barras. A média de renda dos 12 municípios do Primeiro Patamar Metropolitano, sem considerar Curitiba, fica em 0,93\% do salário mínimo.

Em face a estas considerações iniciais, e buscando iniciar uma investigação de bases para fundamentar a articulação de estratégias para uma sustentabilidade regional, são agora analisados, de forma preliminar, alguns dados referentes aos doze municípios que compõem o recorte espacial aqui focalizado - o "Primeiro Patamar Metropolitano". O objetivo é uma análise comparativa que especifique, inicialmente em números, a relação entre alguns dados básicos da capital paranaense e os municípios contíguos do aglomerado metropolitano, para subsidiar futuro aprofundamento dos estudos da dinâmica metropolitana com vistas à construção continuada das condições de sustenta-bilidade. São analisados dados referentes a:

- população dos municípios; a média do patamar com e sem considerar Curitiba nos anos censitários de 1991 e 2000;

- taxa de crescimento populacional no período 1991-2000;

- Índice de desenvolvimento humano-IDH;

- Renda per capita;

Inicialmente, analisando os contingentes populacionais, verifica-se que Curitiba concentra $62 \%$ da população dos doze municípios que compõem o Primeiro Patamar Metropolitano, que é de 2.559.353 habitantes (Censo ano 2000), e se destaca com grande diferença positiva de população em relação ao município que fica em segundo lugar quanto ao número de habitantes, São José dos Pinhais, na proporção de 7,77 vezes. Considerando a média populacional dos municípios do patamar, que é de 213.279 habitantes, verifica-se que esse número, em relação a população de Curitiba, guarda uma proporção de 7,44 vezes menor. Ou seja, a proporcionalidade da população da maior cidade do aglomerado metropolitano, Curitiba, com as cidades que conformam o contexto do aglomerado urbano contínuo da Região Metropolitana guarda uma diferença similar à que se observa entre a população de Curitiba e de São José dos Pinhais, o segundo município mais populoso dentre os doze municípios do patamar. No entanto, ao se retirar Curitiba do cálculo da média de população do Primeiro Patamar Metropolitano, verifica-se, com dados do ano 2000, que a média populacional diminui para 88.405 habitantes, o que situa o pólo metropolitano ainda mais distanciado da realidade que o circunda: $a$ capital paranaense possui 1.586.898 habitantes e é rodeada por onze municípios cuja população média é cerca de dezoito vezes menor que a sua (exatamente 17,95). Com esses valores numéricos é possível visualizar um grande desnível de densidade populacional entre os municípios do aglomerado urbano contínuo, polarizado em Curitiba - situação referenciada pela denominação aqui utilizada de 'patamar' para os níveis de aglomeração urbana da Região Metropolitana de Curitiba, conforme se apresenta no gráfico 1 . 
LIMA, C. de A. Multiespacialidades metropolitanas e construção social do lugar...

GRÁFICO 1 - COMPARATIVO ENTREA POPULAÇÃO TOTAL DE CURITIBA EA MÉDIADE POPULAÇÃO DOS OUTROS ONZE MUNICÍPIOS QUE COMPÕEM O PRIMEIRO P ATAMAR DEAGLOMERAÇ̃̃O URBANADA REGIÃO METROPOLITANA DE CURITIBA-ANOS 1991 E 2000 (EXCET O CURITIBA). COMPARING CURITIBA'S TOTAL POPULATIONS TO THE AVARAGE POPULATION OF 11 OTHER MUNICIPALITIES WHICH MAKE UP THE URBAN COMPOUD OF CURITIBA'S METROPOLITAN REGION.

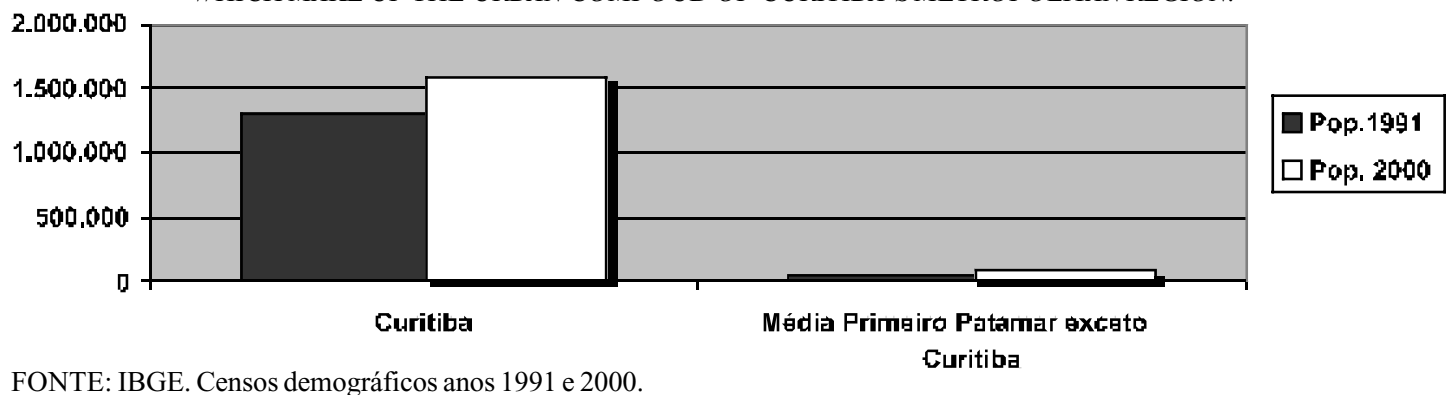

TABELA 1 - POPULAÇÃO DOS MUNICÍPIOS DO PRIMEIRO PATAMAR METROPOLITANO -ANOS 1991 E 2000, E TAXADE CRESCIMENTO NO PERÍODO 1991 - 2000. MUNICIPALITIES POPULATION IN RELATIONTO THE FIRST METROPOLITANRANK- FROM 1991 TO 2000,AND GROWTHTAX FROM 1991 TO 2000.

\begin{tabular}{|c|c|c|c|}
\hline Musicípio & $\begin{array}{l}\text { Populaçẵo } \\
\text { lolal Ano } 1991\end{array}$ & $\begin{array}{l}\text { Populaţắ } \\
\text { (a)tal Ano } 20000\end{array}$ & $\begin{array}{l}\text { Taxid de } \\
\text { arescimento } 1991- \\
2000\{\% \text { a.d })\end{array}$ \\
\hline $\begin{array}{l}\text { 1. Almirante } \\
\text { Iamantalé }\end{array}$ & 66.159 & 88.139 & 4,82 \\
\hline Araucária & 61.889 & 94.137 & 5,26 \\
\hline $\begin{array}{l}\text { 3. Campina } \\
\text { Girande do Sul }\end{array}$ & 19.34 .3 & 35.107 & 9,05 \\
\hline Campo l, argo & 72.523 & 92.713 & 2.81 \\
\hline 5. Campo Magro & $*$ & 29.364 & 5,57 \\
\hline 6. Colonshn & 117.767 & 183.353 & 4,51 \\
\hline 7. C'uritiba & 1.315 .035 & 1.586 .898 & 2,13 \\
\hline $\begin{array}{l}\text { 8. Fazendea Rio } \\
\text { Gtrande }\end{array}$ & 24.997 & 62618 & 8,43 \\
\hline 9. Tinhais & 75.536 & 102.871 & 3,59 \\
\hline 10. Piraquara & 31.346 & 72.806 & 8,53 \\
\hline $\begin{array}{l}\text { 11. Quatro } \\
\text { Barra: }\end{array}$ & 10.9007 & 16.149 & 6,82 \\
\hline $\begin{array}{l}\text { 12. Săo Tosé dos } \\
\text { Jinhais }\end{array}$ & 127.455 & 204.198 & 4,84 \\
\hline Média clo pataunar & 174.732 & 213.279 & $5,5,53$ \\
\hline $\begin{array}{l}\text { Média do patamar } \\
\text { sèm toulitiba }\end{array}$ & 610.7102 & 88.4115 & 5,84 \\
\hline RMC: & 2.055 .455 & 2.726 .556 & 3,17 \\
\hline T'arallá & 8.448 .981 & 9.558 .454 & 1,39 \\
\hline
\end{tabular}

FONTE: IBGE - Censos demográficos; População projetada 2010 - Ipardes. Caracterização das regiões metropolitanas institucionalizadas. Região Sul. Versão Preliminar. Convênio IPEA/IBGE/Unicamp/Ipardes, ago. 1999.

OBS.: * Os dados da população de Campo Magro não figuram na tabela para o Censo de 1991 pela razão de naquele ano ainda integrar o município de Almirante Tamandaré. 
LIMA, C. de A. Multiespacialidades metropolitanas e construção social do lugar...

Os números da população dos municípios em pauta se encontram na tabela 1 .

Os números da tabela 1 confirmam que, de todos os municípios do Primeiro Patamar Metropolitano, Curitiba é o que vem apresentando a menor taxa de crescimento, 2,13\% ao ano, tendência conhecida desde a divulgação da Contagem Populacional do IBGE realizada em 1996. No entanto, neste momento, o item importante a registrar é a velocidade que adquire o crescimento da demanda por infra-estrutura, habitação, serviços urbanos, oportunidades de emprego e renda na periferia configurada no crescimento dos municípios vizinhos a Curitiba no período 1991-2000 e que vem se mantendo em trajetória ascendente segundo os dados do último censo. Ressalte-se o desequilíbrio entre demanda e capacidade de atendimento das administrações municipais justamente nas localidades onde a dinâmica econômica é menos intensa e já registrava carência de infra-estrutura e serviços públicos em geral, em alguns casos desde a década de setenta e oitenta, quando se verificou uma intensificação da ocupação periférica a Curitiba, em decorrência de um processo de modernização da agricultura no Estado (LIMA, 2000). Assim,onde há mais infra-estrutura - Curitiba -, o crescimento populacional é menor; nos municípios periféricos, onde a estrutura urbana é carente, o crescimento populacional é maior. Essa é uma situação a ser considerada para o planejamento das ações públicas dos anos subseqüentes e na averiguação das bases de concentração ou dispersão populacional em relação ao fomento da sustentabilidade na regiãometropolitana.

\section{Velocidade e dimensão das demandas e o desenho urbano}

Ao mesmo tempo em que se considera a aceleração das demandas por infra-estrutura, serviços e equipamentos públicos, decorrente da velocidade do crescimento populacional, também se consideram as dimensões e a escala que assumem essas demandas. A escala e urgência das demandas são especificadas pela proporção em relação ao montante populacional, cuja diversidade ou similaridade em quantidade de habitantes está representada no gráfico 2, a seguir. Cabe enfatizar o peso das condicionantes quantitativas em relação à capacidade de atendimento das administrações públicas dos municípios menos estruturados, mas também o fator agravante representado

GRÁFICO 2 - POPULAÇÃO TOTAL EM 2000 EM DOZE MUNICÍPIOS QUE COMPÕEM O PRIMEIROP ATAMAR DE OCUPAÇÃO URBANA DAREGIÃO METROPOLITANADE CURITIBA - RMC (EM NÚMEROS ABSOLUTOS). TOTAL POPULATION IN 2000 IN 12 MUNIPALITIES WHICH MAKE UP THE URBAN COMPOUD OF CURITIBA'S METROPOLITANREGION.

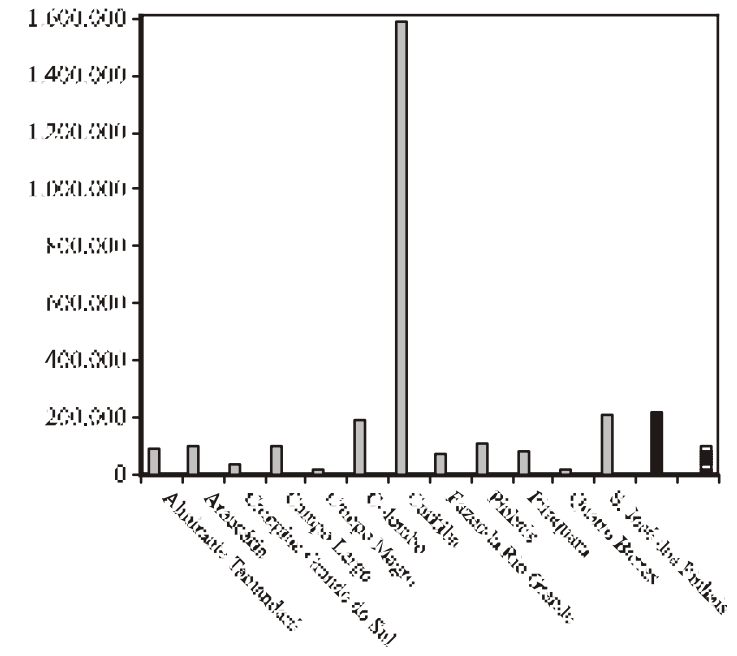

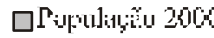

Médias Propuliabiou:ial

目Médiı som Curilibs:

FONTE: IBGE. Censo populacional 2000. 
LIMA, C. de A. Multiespacialidades metropolitanas e construção social do lugar...

pelas determinantes qualitativas, ou seja, as demandas são também proporcionais às carências determinadas pelas características socioeconômicas da população, comonível de renda, taxa de emprego, escolaridade, condições de saú$\mathrm{de}$, dentre outras. E, finalmente, ressalte-se que asrespostas às demandas por infra-estrutura, serviços e equipamentos públicos são também influenciadas pelo padrão de ocupação e o desenho do aglomerado urbano - tanto na sua configuração técnica quanto no custo de implantação e manutenção e seja a ocupação legal ou ilegal.No caso da Região Metropolitana de Curitiba, observa-se um padrão de horizontalidade prevalecente na mancha urbana que apenas vai encontrar um contraponto com o padrão de ocupação das vias estruturais dentro do perímetro urbano curitibano.

Analisando apenas os números totais apresentados no gráfico 2, surgem questões: a extensão e o custo das redes de infra-estrutura e serviços não poderiam ser mais concentradas para maior otimização de materiais, recursos e também de tempo de deslocamento dos moradores? $\mathrm{Na}$ trajetória de expansão urbana da Região Metropolitana de Curitiba, as redes públicas de infra-estrutura e serviços não deveriam ter um limite-ótimo em relação ao comprimento, não equivalente à atual distância arbitrária do centro do aglomerado urbano até as suas bordas, rompendo com o padrão horizontal que equipara o quantitativo populacional à extensão das redes?

Observando o gráfico 2, divide-se o quantitativo populacional registrado no último censo populacional em quatro grupos segundo similaridade em número de habitantes. O primeiro grupo é o relativo unicamente a Curitiba, com sua população de 1.587 .315 habitantes. O segundo grupo reúne os municípios de São José dos Pinhais e Colombo, que possuem população próxima dos 200.000 habitantes, ou seja, $1 / 8$ da população de Curitiba; o terceiro grupo reúne Almirante Tamandaré, Araucária, Campo Largo, Fazenda Rio Grande, Pinhais e Piraquara, que possuem população entre 60 e 100.000 habitantes, e, por último, o quarto grupo, que reúne os municípios de Campina Grande do Sul, Campo Magro e Quatro Barras, que têm entre 16.000 e 35.000 habitantes no total da população municipal.

Em relação ao primeiro grupo, considerando a dinâmica de crescimento populacional e demanda por infraestrutura, serviços e equipamentos públicos, como o processo de urbanização de Curitiba já apresenta uma trajetória de mais de 30 anos desde o início da implantação do atual Plano Diretor, sabe-se que o atendimento à demanda já conta com uma quantidade razoável de itens implantados e que continuam atendendo à população, como rede de coleta e distribuição de água, energia, transporte coletivo, pavimentação de ruas, escolas, unidades de saúde, bibliotecas públicas, museus, etc. Entretanto, mesmo com crescimento anual da sua população inferior às taxas de crescimento populacional dos municípios vizinhos, Curitiba atingiu um volume de habitantes que significa encargos continuados de criação ou renovação, atendimento e manutenção de edificações, serviços, espaços livres, recursos materiais e humanos muito superiores aos demais municípios quando se consideram:

- o montante da clientela diária;

- as características físicas e operacionais dos serviços do sistema público oferecido;

- número de unidades de atendimento, como postos de saúde, escolas, etc;

- número de profissionais envolvidos (médicos, assistentes sociais, professores, etc.);

- nível de exigência da população-que passa a aumentar à medida do aperfeiçoamento do atendimento e do aumento do grau de formação educacional, renda e/ou de informação dos habitantes.

A par disso, observe-se que as populações, em geral, vêm adquirindo maior consciência de seus direitos; de ser o serviço público pago pelo cidadão; noções de estruturação do sistema social em decorrência de mais acesso a informação, mesmo que pela mídia mais popular, a conhecimentos relativos a procedimentos, materiais ou equipamentos, quer sejam relativos a tratamento de saúde, educação, informação e outros itens culturais atuais e que, principalmente, sejam objeto dos meios de comunicação."

11 Para alguns serviços públicos, notadamente aqueles ligados às áreas de saúde e educação, nos pólos de urbanização concentrada observa-se a demanda ampliada pelos habitantes dos municípios vizinhos, que geralmente integram a força de trabalho da cidade-pólo. 
LIMA, C. de A. Multiespacialidades metropolitanas e construção social do lugar...

\section{População, renda e capacidade de inserção na cidade legal}

As taxas de crescimento apresentadas pelos municípios entre 1991 e 2000 (tabela 1) levam a reflexões a respeito da relação entre a velocidade do crescimento populacional e a capacidade da população de arcar com os custos financeiros advindos da sua eventual inserção em um contexto legal de ocupação urbana, como compra de terreno de loteamento aprovado e aquisição, construção ou aluguel de casa ou apartamento. Nessa situação se somariam despesas com a aquisição do imóvel ou decorrentes de aluguel mensal; impostos e taxas anuais e mensais; despesas condominiais mensais ou com a manutenção do imóvel próprio ou alugado. As taxas de crescimento populacional comparadas com a condição financeira representada por índices como o que classifica a rendaper capita e o Indice de Desenvolvimento Humano - IDH ${ }^{12}$ - permitem visualizar os municípios nos quais é necessário e seria adequado o fortalecimento prioritário de ações públicas decorrentes de estratégia de desenvolvimento econômico com foco na geração de oportunidades de emprego e/ou renda; no desenvolvimento social com ênfase nas condições de vida da população como saúde, educação e formação para o trabalho; fomento ao associativismo e realização de projetos de vida, incluindo apoio aos fatores psicológicos e emocionais da população de baixa renda, como resgate de autoestima e valores pessoais e de grupo que alavanquem posturas cidadãs. Os dados do gráfico 3 conferem condições para algumas reflexões iniciais.

No gráfico 3 foi feito um comparativo entre taxa de crescimento populacional no período 1991-2000 com Índice de Desenvolvimento Humano - IDH - do ano 2000 e, por fim, com os valores da renda per capita média do município, no caso dividida por cem, para fins de visualização.
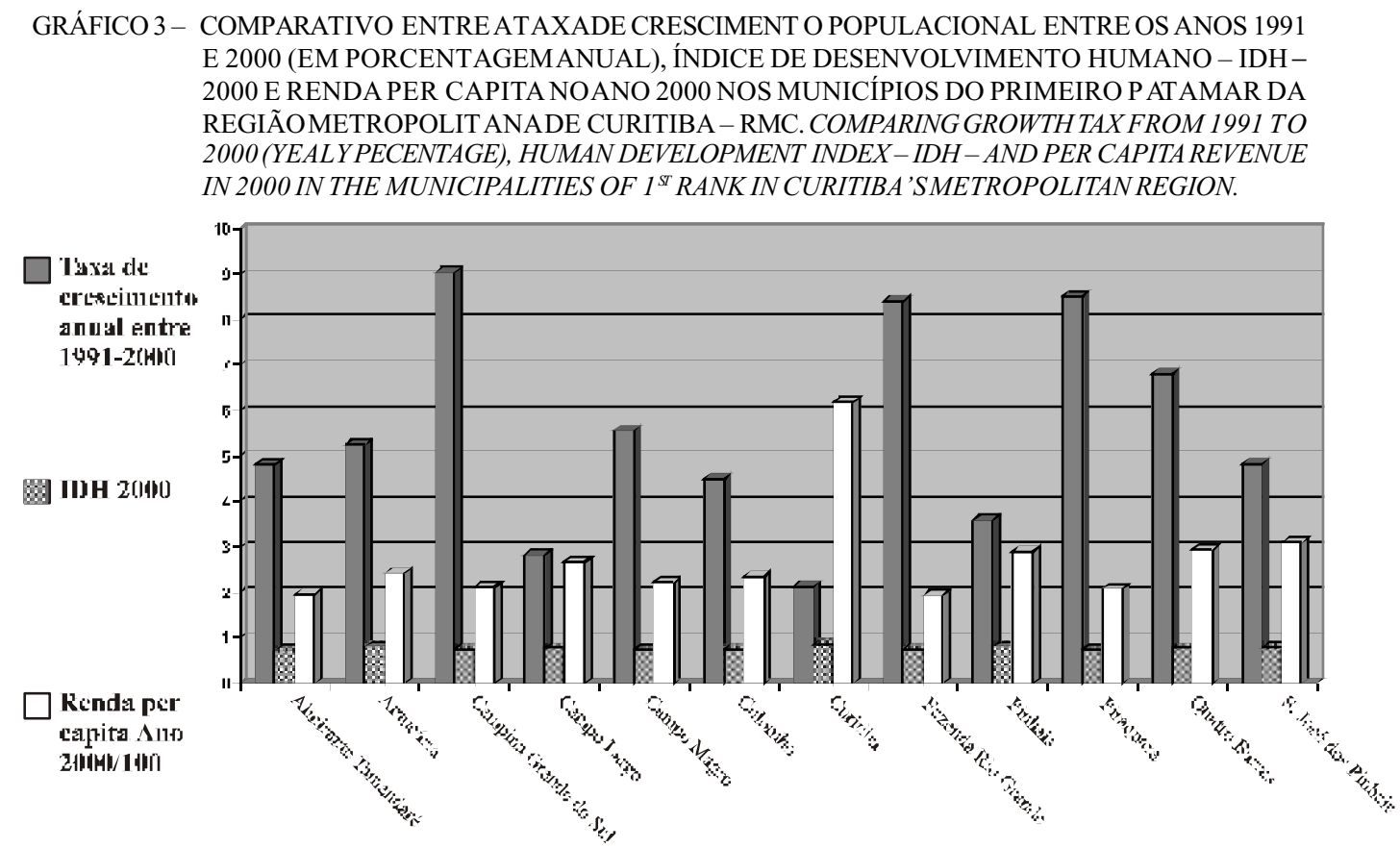

FONTE: IBGE. Censos populacionais. 12 Índice de desenvolvimento humano - IDH - é índice utilizado nos Relatórios de Desenvolvimento Humano publicados pelo PNUD desde 1990 com resultado da
avaliação de três condições de vida de população: educação, longevidade e renda. 
LIMA, C. de A. Multiespacialidades metropolitanas e construção social do lugar...

Em relação à taxa de crescimento populacional, destacam-se dois extremos: de um lado, os municípios que apresentam taxas de crescimento acima da média do patamar, que é de 5,53\% ao ano. Nessa condição encontram-se os municípios de Campina Grande do Sul (9,05\% a.a.), Fazenda Rio Grande (8,43\% a.a.), Piraquara (8,53\% a.a.) e Quatro Barras (6,82\% a.a.). Esses municípios apresentam Índice de desenvolvimento Humano abaixo da média do patamar, que é de 0,776 . Já no extremo oposto estão os municípios com menores taxas de crescimento. Curitiba apresenta a taxa de crescimento mais baixa - 2,13\% entre 1991 e 2000 -, enquanto seu IDH é o mais elevado do conjunto dos 12 municípios. Em segundo lugar em taxa de crescimento baixa está o município de Campo Largo, que apresenta taxa de 2,81\% a.a., porém seu IDH está em quinto lugar no patamar, junta- mente com Quatro Barras, cujo IDH está abaixo da média do conjunto e que tem taxa de crescimento de $6,82 \%$ a.a., quase duas vezes e meia maior que a taxa de crescimento populacional apresentada por Campo Largo no mesmo período. Em terceiro lugar com a menor taxa de crescimento no Primeiro Patamar Metropolitano está o município de Pinhais, com taxa anual de 3,59\% a.a. e o segundo melhor IDH logo abaixo de Curitiba.

Considerando três categorias de análise: taxa de crescimento populacional, Índice de Desenvolvimento Humano (IDH) e renda per capita, fez-se uma avaliação com ênfase para renda, razão para este fator aparecer tanto no cômputo do IDH e haver sido também considerado como valor em si. Na análise feita, foi conferida melhor avaliação aos municípios que apresentam taxas de crescimento menores,

QUADRO 1 - CLASSIFICAÇÃO DOS MUNICÍPIOS DO PRIMEIRO PATAMAR METROPOLITANO EM FUNÇÃO DE AVALIAÇÃO PRELIMINAR DOS RESULTADOS QUANT O À TAXADE CRESCIMENTO POPULACIONALNO PERÍODO 1991-2000, ÍNDICE DE DESENVOLVIMENTO HUMANO - IDH - NO ANO 2000 E RENDA PER CAPITA NO ANO 2000. CLASSIFYINGMUNICIPALITIES OF $1^{\text {ST }}$ RANK CONCERNING POPULATION GROWTH FROM 1991 TO 2000, HUMAN DEVELOPMENT INDEX -IDH - IN 2000AND PER CAPITA REVENUE 2000.

\begin{tabular}{|c|c|c|c|c|c|c|c|}
\hline $\begin{array}{l}\text { Cassiti } \\
\text { apa }\end{array}$ & Municipitr & 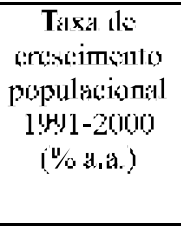 & 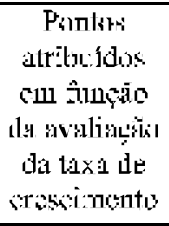 & $\begin{array}{l}\text { TDVT - } \\
2000\end{array}$ & 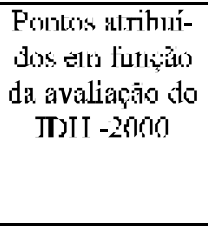 & 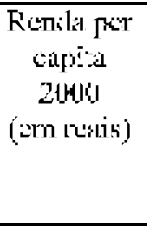 & 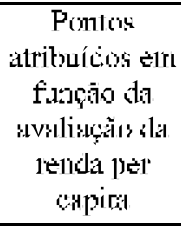 \\
\hline 1. & - Curjtilsá & 2,13 & 12 & 0,856 & 12 & 619,822 & 12 \\
\hline 2. & - Pinlonis & 3,50 & 10 & $0.8: 5$ & 11 & 392,982 & 9 \\
\hline \multirow[t]{2}{*}{3} & - Campo L argo & 2.81 & 11 & 1,771 & 8 & 267,312 & 8 \\
\hline & $\begin{array}{l}\text { - São José das } \\
\text { Pinlais; }\end{array}$ & $4, \$ 4$ & 7 & 0.796 & $y$ & 311.289 & 11 \\
\hline 4. & - Arauch́ria & 5.26 & 6 & 0.801 & 10 & 242,059 & 7 \\
\hline \multirow[t]{2}{*}{5.} & - Colombo & 4.51 & 9 & 0.764 & 7 & 236,158 & 6 \\
\hline & - Qniztro Bartas & $6, \$ 2$ & 4 & 0.774 & 8 & 294,642 & 10 \\
\hline 6. & - Campi Mryro & 5,57 & 5 & 1), $7<0$ & 3 & 223,675 & 5 \\
\hline 7. & $\begin{array}{l}\text { Al-niranlt: } \\
\text { Türnandaré }\end{array}$ & 4,82 & 8 & 0.728 & 2 & 197,645 & 2 \\
\hline \multirow[t]{2}{*}{8} & $\begin{array}{l}\text { - Campritr } \\
\text { Gratede co Sul }\end{array}$ & 9,05 & 1 & 0,762 & 5 & 212,535 & 4 \\
\hline & $\begin{array}{l}\text { - Firenkla Rib } \\
\text { Gracde }\end{array}$ & 8,43 & 3 & D. 76.3 & 6 & 194,313 & 1 \\
\hline 9. & - P’jraqualá & 8,53 & 2 & $0,7<4$ & $\angle$ & 208,887 & 3 \\
\hline
\end{tabular}

FONTE: IBGE. Censos populacionais 1991 e 2000. 
e, quanto a IDH, conferindo melhor avaliação aos municípios que detêm índices mais altos, assim como quanto à renda per capita a melhor avaliação partiu da renda mais alta. Dessa forma, mesmo com consciência do caráter incipiente da avaliação, chegou-se a determinar uma seqüência decrescente a partir da melhor condição, conforme exposto no quadro 1 .

Considerando os dados do quadro 1, podem ser identificados 3 subgrupos nesse Primeiro Patamar Metropolitano, em função das diferenças entre taxa de crescimento, IDH e renda per capita. O município de Curitiba sozinho compõe o primeiro subgrupo, com uma avaliação em 36 pontos, e estabelece a distância para um segundo subgrupo, composto por 6 municípios, que apresenta resultados variando desde 30 até 22 pontos. E por fim, um terceiro subgrupo, composto por cinco municípios, apresenta a variação desde treze até nove pontos:

\section{Subgrupo A: Curitiba; \\ Subgrupo B: Pinhais, Campo Largo, São José dos Pinhais, Araucária, Colombo e Qua- tro Barras;}

Subgrupo C: Campo Magro, Almirante Tamandaré, Campina Grande do Sul, Fazenda Rio Grande e Piraquara.

Destaque-se que dentre os doze municípios do Primeiro Patamar Metropolitano, apenas quatro municípios (ou $33,33 \%$ ) apresentam Índice de Desenvolvimento Humano acima da média do patamar. Os demais 66,66\% estão abaixo de 0,776 , sendo que a média desse índice na Região Metropolitana toda, considerando os vinte e sete municípios, éainda mais baixa, tendo ficado no ano $2000 \mathrm{em} \mathrm{0,742.}$

Ainda cabe considerar que na análise dos doze municípios, considerando-se a taxa de crescimento populacional e o IDH, dez municípios estão crescendo acima da média da região metropolitana e cinco crescem a taxas mais altas do que a média do patamar, conformado pelos doze municípios em foco neste artigo. O municipio de Campina Grande do Sul cresce a 9,05\% a.a., taxa que significa 4,25 vezes mais do que a taxa de crescimento anual apresentado por Curitiba. O agravante é que esse município apresenta índice de desenvolvimento humano abaixo da média do patamar, ou seja, é um alvo preferencial para políticas públicas de promoção humana, como também os demais municípios reunidos no subgrupo C. As questões sociais necessitam ser contempladas com urgência nesses municípios, assim como nos demais do Patamar e mesmo em Curitiba, mas especialmente em Piraquara, que apresenta taxa de crescimento anual de $8,53 \%$ a.a. e IDH abaixo da média do patamar. Assim também, Fazenda Rio Grande, que cresce a $8,43 \%$ a.a. e também tem IDH abaixo da média do patamar, e Quatro Barras, que cresce a 6,82\% e apresenta um IDH muito próximo da média, assim como o município de Campo Largo, que, por sua vez, tem crescimento populacional em 2,81\% a.a. Assim, o IDH de Campo Largo também necessita ser elevado, assim como de toda a região.

Portanto, na presente análise, ainda bastante preliminar, e que deverá ser aprofundada em estudos subseqüentes, inicialmente podem-se verificar sinais, mesmo que limitados pelos fatores analisados aqui, que apontam precariedade quanto às condições financeiras para as populações custearem a melhoria do seu padrão de vida, com base nas condições de habitação, transporte, lazer e outros itens. Verifica-se que a renda média mensal é bastante baixa nos municípios que rodeiam Curitiba - cerca de $\mathrm{R} \$ 243,772$ mensais em média - excluindo Curitiba da análise, o que conforma o Primeiro Patamar de adensamento metropolitano como população de renda média de um salário mínimo. Pelos números da renda per capita pode-se justificar a exclusão da população dos loteamentos aprovados para a periferia curitibana informal, em função dos rendimentos mensais apenas cobrirem gastos cotidianos de sobrevivência, em padrões mínimos. No município de Curitiba, a renda média per capita mensal é de quase três vezes a renda média per capita dos demais onze municípios do patamar, considerando o contexto urbano que requer renda para inserção e manutenção do indivíduo ou família como contribuinte municipal em serviços urbanos públicos. Esses custos são uma parte dos recursos necessários para as atribuições da própria administração municipal, que são mais extensas quanto maior o centro urbano. Um dos itens fundamentais é a manutenção da malha urbana. Segundo a Prefeitura Municipal de Curitiba, cada quilômetro de asfalto totalmente novo custa atualmente $\mathrm{R} \$ 1,5$ milhão. ${ }^{13}$ 
LIMA, C. de A. Multiespacialidades metropolitanas e construção social do lugar...

Por fim, cabe lembrar que, paralelamente às demandas por infra-estrutura urbana e serviços públicos, situamse demandas significativas para equipamentos urbanos em geral, especialmente o item fundamental, que é a habitação. O crescimento das ocupações irregulares em Curitiba e na Região Metropolitana de Curitiba foi objeto de artigo anterior $^{14} \mathrm{e}$, desde o último levantamento realizado por órgãos da administração municipal e do Estado, não houve atualização do número existente. No entanto, caso a porcentagem de crescimento das populações irregulares não houvesse aumentado desde 1997/1998, e tivéssemos ainda cerca de $12 \%$ da população metropolitana ocupando subhabitações, esse porcentual significaria cerca de 320.000 pessoas, o que se equipara à população de uma cidade média.

Como atender a um quadro urbano em infra-estrutura, serviços e equipamentos para uma população limitada em recursos para custear as taxas públicas, que são normalmente cobradas, além dos próprios custos familiares de alimentação, saúde, transporte? Como as administrações locais podem custear a infra-estrutura básica para uma população que trabalha fora do município e não tem renda para contribuir com impostos ou contribuições de retorno para o mercado local, ou retornar os investimentos em atividades produtivas?

O debate acerca da sustentabilidade na Região Metropolitana de Curitiba deve englobar considerações de cunho econômico e social para investigar formas de ação pública e coletiva de desenvolvimento em seu sentido amplo, econômico, social e pessoal. Os instrumentos e práticas de planejamento urbano serão úteis para o suporte físico e material que viabiliza, ou não, as atividades da sociedade. No caso em foco, pensa-se em como encaminhar um compartilhamento e extensão da estruturação urbana existente.

\section{Construção social do lugar e sustentabilidade}

Considera-se que a busca por um ambiente urbano mais sustentável passa pelo equilíbrio socioeconômico, em cujo arcabouço se encontram as questões relativas a emprego e desemprego e renda mínima. Acredita-se que somente após resolvidas as limitações de renda mínima para uma família ou indivíduo haverá como arcar com as despesas decorrentes da vida urbana estruturada pelos padrões técnicos condizentes, já presentes na quase totalidade do território de Curitiba e partes da Região Metropolitana, porém não universalizados nesse espaço. Sendo decorrente de uma conjuntura nacional e internacional, a questão do emprego está diretamente vinculada às ocorrências de ocupação informal e sub-habitações nas periferias urbanas. Nem sempre os investimentos promovidos pelo poder público trazem o retorno para as regiões estagnadas. Ao contrário, se observa a tendência de concentração de investimentos em centros dinâmicos e logisticamente interessantes para o mercado nacional ou internacional. Conforme Bezerra e Fernandes, 1999:

os investimentos programados por eixos de desenvolvimento contribuem para redesenhar a configuração territorial do país, na medida em que tais investimentos são seletivos, privilegiando espaços dinâmicos e relegando áreas de baixo dinamismo ou estagnadas. Isso acentua a tendência de concentração da população urbana nas áreas metropolitanas e nas aglomerações urbanas, reforçando desequilíbrios da rede de cidades e tornando agudos os problemas sociais, urbanos e ambientais dos grandes centros - particularmente porque os investimentos feitos ou programados nesses eixos também não levam em conta os danos ambientais decorrentes.

O padrão de expansão urbana horizontal de baixa densidade, que é praticado na Região Metropolitana de Curitiba, quando é analisado sob o ponto de vista da cobertura do atendimento da infra-estrutura, serviços públicos e equipamentos-existência e manutenção-mais as ocorrências recorrentes de ocupações irregulares, conforma um quadro precário quanto à sustentabilidade - tanto nos aspectos ambientais decorrentes dessa situação quanto do ponto de vista do desenvolvimento econômico, social e de promoção humana. Como exposto anteriormente neste artigo, há uma cidade média - se considerarmos o montante estimado de 320.000 pessoas que habita as sub-habitações no espaço aqui considerado - que está alijada do sistema urbano legal e tecnicamente estruturado. Essa formatação econômica deverá mudar se o objetivo for a sustentabilidade, porém as soluções urbanas e sobretudo

14 LIMA, C. de A. Considerações sobre ocupações irregulares e parcelamento urbano em áreas de mananciais da Região Metropolitana de Curitiba. Desenvolvimento e Meio Ambiente, Curitiba, n. 3, p. 97-114, 2001. 
as sociais também. A grande maioria das soluções até aqui desenvolvidas impede que os orçamentos municipais atendam às demandas da população. Deficiências administrativas à parte, cabe considerar, como afirmam Acioly e Davidson (1997), que os custos da infra-estrutura em assentamentos de baixa densidade são bastante altos e, a exemplo das superquadras de Brasília, tornam a sustentabilidade urbanavulnerável.

No panorama do Primeiro Patamar Metropolitano, há deficiências em infra-estrutura e equipamentos a serem atendidas, em alguns locais em proporções significativas, principalmente quanto a saneamento, ou seja, coleta, separação e tratamento do lixo doméstico e industrial; drenagem, coleta de esgoto e, ainda mais, no tratamento de esgoto doméstico e industrial. ${ }^{15}$ Também há necessidade de construção e manutenção de edificações para atendimento comunitário como escolas e postos de saúde, além da pavimentação e manutenção das vias urbanas e rurais, e itens complementares de arruamento como passeio e meio-fio, instalação de equipamento e mobiliário urbano, paisagismo, iluminação. Tais lacunas do cenário urbano são dificilmente preenchidas por causa do alto custo de instalação e manutenção, comparado aos limitados recursos públicos, os quais, por sua vez, existem como decorrência, em parte, de arrecadações tributárias provenientes de serviços e produtos gerados pela base produtiva local. ${ }^{16}$ Assim, deve haver haver geração de riqueza dentre a população para que existam recursos para custear a infra-estrutura, sua instalação e manutenção do sistema urbano público.

Em relação a atividades de iniciativa pública, há uma tarefa igualmente fundamental visando aodesenvolvimento do capital humano. Além da promoção das condições adequadas de saúde e educação, também deve ser priorizada a formação técnica, a inserção profissional e mesmo social dos indivíduos por meio da articulação coletiva. A motivação das comunidades é um alvo a ser estabelecido em fun- ção do crescimento comum, seja pela geração de renda, aperfeiçoamento profissional ou outras formas de organização comercial ou industrial.

A abordagem da otimização do uso do solo urbano, de forte base ambiental, tem também fundamentação econômica no contexto da gestão pública e dos orçamentos das famílias de moradores. São necessárias mais investigações a respeito da relação custo-benefício do aumento das densidades de ocupação das áreas urbanizadas, de forma diferenciada. Especialmente para as classes de menor ren$\mathrm{da}$, deveriam ser incentivados estudos sobre vantagens e desvantagens ambientais e socioeconômicas das formas de assentamento de média e alta densidade em que o custo da infra-estrutura instalada possa ser viável para as famílias, de forma a manterem ao longo do tempo a qualidade ambiental dos espaços urbanos ${ }^{17}$ com retorno para o grupo comunitário. Não só a densidade, mas o custo de redes de coleta e tratamento de esgoto ficam geralmente fora do alcance dos programas de habitação popular, dos programas de atendimento dos bairros periféricos mais pobres, apesar de serem primordiais. Um exemplo inovador a ser citado é o das duas favelas da cidade de Natal, no Estado do Rio Grande do Norte, relatado por Acioly e Davidson (1997). Nas favelas de Rocas e Santos Reis, foi adotada uma solução para o esgotamento sanitário por meio de rede condominial que passa pelo fundo dos lotes, a um custo de US\$350 por família. A eficiência do sistema levou a que ele fosse implantado em outros projetos de urbanização de favelas e lotes urbanizados em Natal e em outras cidades brasileiras. As avaliações que foram feitas do sistema mostraram que houve uma redução expressiva dos custos da infra-estrutura por família e que o custo diminui à medida que aumenta a densidade demográfica no assentamento, a ponto de poder substituir a solução de "fossas sépticas". Quando a densidade demográfica atinge 160 habitantes por hectare ou mais, há uma diminuição do custo para US\$48,00 por família.

\footnotetext{
15 Segundo dados de censos.

16 Referência à circunstância de, no âmbito local, as fontes de recursos das administração públicas serem provenientes do controle das propriedades e das corporações de ofício, ou seja, o Imposto Predial e Territorial Urbano (IPTU), com taxas cobradas em função das características do imóvel urbano, e o Imposto Sobre Serviços (ISS), que recolhe porcentual do recurso advindo das atividades profissionais de autônomos.

17 Nos bairros de baixa renda, para a qualidade urbana há necessidade de haver a manutenção dos espaços comuns, como ocorre nas demais áreas da cidade. Ou seja, a população deveria ter condições de contribuir, por meio das taxas municipais, para serviços de varredura, coleta de lixo e limpeza pública; controle de setores; manutenção de arborização urbana e equipamentos de uso coletivo, como brinquedos infantis, bancos, telefones públicos, quadras esportivas e itens similares. Outra alternativa é a adoção dos locais por entidades privadas, como tem sido feito com a manutenção de praças em São Paulo; áreas ajardinadas de ruas e edifícios do Estado em Curitiba.
} 
LIMA, C. de A. Multiespacialidades metropolitanas e construção social do lugar...

Segundo o professor e consultor Eric Heikkila, ${ }^{18}$ da Universidade do Sul da Califórnia, que participa de pesquisa sobre habitação financiada pela Organização das Nações Unidas (ONU), devem ser pensadas maneiras de promover, por exemplo, a geração de empregos nos conjuntos de casas populares. Para tanto, afirma que podem ser investidos recursos públicos ou privados, sendo que para atrair o investimento privado deve haver possibilidades de retorno vantajoso para a soma aplicada pelo investidor. Assim, como nos casos das parcerias entre governo e iniciativa privada, há que se mobilizar investimentos e criar condições favoráveis para a concretização dos programas sociais. Nesse sentido, muitas vezes a legislação tem de ser modificada, como nos casos de regularização das construções informais - pois pensa-se como Heikkila, que "os padrões de ocupação precisam ser mais realistas"sendo que um dos fatores de exclusão da cidade legal tem sido o alto custo dos imóveis, valorizados por ações decorrentes de planejamento e ampliados pelo mercado imobiliário, que não está focado na população de baixa ren$d a$, que é a mais necessitada e cresce em proporção maior que as camadas mais favorecidas. Enfim, acredita-se que a cidade que funciona de forma sustentável é a que apresenta possibilidades para a população, como um todo, usufruir de qualidade de vida para suporte das trajetórias coletivas e individuais. Nas palavras de Acioly e Davidson (1997),

A produtividade das cidades é medida através do grau de eficiência com que elas conseguem maximizar investimentos públicos e privados e pela capacidade de gerar seus próprios recursos, necessários para manter um processo de desenvolvimento contínuo e sustentável.... A cidade sustentável terá que surgir de uma prática do planejamento e gestão do meio ambiente urbano que leve em conta não somente aspectos ligados ao bem estar social dos habitantes mas também aos aspectos econômicos e financeiros intrínsecos às morfologias e tipologias das cidades.

Os procedimentos técnicos de organização territorial metropolitana da Região Metropolitana de Curitiba, até aqui, de forte cunho territorial, poderiam ser aproveitados na pesquisa e efetivação de programas focados na construção social do lugar para inserção de identidade individual e coletiva, inserção social e técnico-profissional das populações e otimização das ocupações consolidadas e novas visando a um ambiente urbano mais sustentável.

\section{Considerações finais}

Se não há passos definidos para formatar a sustentabilidade de um aglomerado metropolitano, cabe analisar a realidade e propor a ação julgada mais adequada. Esse julgamento, no entanto, quanto mais ajustado aos reais anseios da população provavelmente será mais sustentado. Verifica-se que, a par do fato conhecido de Curitiba apresentar uma situação privilegiada no contexto nacional, e também na sua própria região metropolitana, quanto a estruturação urbana, planejamento e gestão, existem aspectos a serem avaliados no contexto do aglomerado urbano polarizado pela capital do Estado do Paraná que, se objeto de adequadas ações do Poder Público podem encaminhar para uma crescente condição de sustentabilidade metropolitana.

Curitiba tem uma ocupação urbana continuada ao seu redor que extrapola seus limites político-administrativos. Trata-se de uma conurbação densa principalmente nos principais eixos viários que fazem a ligação da cidade com sua região, o interior do Estado e dos Estados vizinhos. Nessas áreas observam-se ocupações formais e informais, residências, indústrias, serviços de beira de estrada e outras atividades que conformam um uso do solo e uma paisagem urbana bastante variada e predominantemente inferior àquela da área central curitibana, especialmente quanto a infraestrutura, serviços urbanos e o conjunto de elementos da relação cidade e meio ambiente. ${ }^{19}$ Ainda dentro dos limites do município-pólo da Região Metropolitana de Curitiba (RMC), há aspectos de deficiência de infra-estrutura. No entanto, considera-se que são problemas que podem ser solucionados mais facilmente em razão do porte e estrutura administrativa, técnica e financeira existente em Curitiba. O que é enfatizado neste artigo, contudo, é a necessidade do aperfeiçoamento de pesquisas e estudos para embasamento de experiências de planejamento e gestão, com a materialização de soluções urbanas concretas e de custo

18 DEUS, Sérgio Luis de. Boas intenções não são suficientes. Gazeta do Povo. Curitiba, 11 jun. 2004, p. 10.

19 Referência a itens como a qualidade do espaço urbano formado pelas edificações, morfologia, sistema viário como espaço de circulação, vegetação urbana, sinalização, equilíbrio de volumes, perspectiva, dentre outros elementos que, ao serem avaliados, subsidiam essa posição da autora. 
acessível que englobem a população excluída na cidade legal. Nessa linha de pensamento, descartando qualquer intenção de uniformização ou regularidade, deveriam ser reforçadas as centralidades do aglomerado urbano que forma o anel do aglomerado urbano. Excetuando-se a capital, é nesse anel periférico, o aqui chamado "Primeiro Patamar Metropolitano", no qual se observam os mais altos índices de crescimento populacional em uma dinâmica socioeconômica e ambiental que delineia um questionamento concreto e eloqüente quanto à sustentabilidade urbana do pólo metropolitano e, ainda mais, quanto à viabilidade de estendê-la até as bordas desse patamar.

Acredita-se que a sustentabilidade estaria melhor encaminhada se houvesse mais equilíbrio na participação ativa da população na construção do lugar, no sentido de reforçar a construção coletiva, a identidade e os laços da população com os resultados materiais e sociais do espaço construído. Percebem-se grandes disparidades nas condições de vida de todo o Primeiro Patamar Metropolitano. No entanto, talvez mais significativa do que o equilíbrio das bases econômicas e de educação seja a política de efetivação de espacialidades materiais e sociais peculiares às diferentes comunidades. Soluções de atendimento às necessidades básicas de infra-estrutura e serviços que focalizem a ligação do indivíduo com a coletividade em um espaço específico. A atuação da população na decisão das políticas e programas por meio da definição de prioridades na aplicação dos recursos disponíveis tem sido feita em municípios brasileiros e acredita-se que seja uma etapa extremamente válida.

A realidade dual entre pólo e periferia do aglomerado metropolitano retrata bem a valorização imobiliária do território em função da estruturação e equipamentação urbana, vinculada aos setores produtivos e camadas da população com capacidade financeira para interagir em um cenário urbano idealizado. Na Região Metropolitana de Curitiba ainda não se observa a participação pública efetiva, o que não acelera a construção de uma real coesão como ente metropolitano, no sentido de efetivar políticas públicas e ações conjuntas das diversas administrações municipais, em benefício do aglomerado urbano comum. Curitiba permanece como pólo absoluto para as principais demandas de serviços públicos como saúde, educação média e superior, comércio especializado, lazer. No entanto, o atendimento das necessidades básicas da população e o aumento do seu grau de satisfação poderia ser obtido em cenários urbanos diversos do padrão conhecido e definido como ideal. Dupas (1999) cita o pensamento de Giddens e o trabalho de Murray (1988), sendo que para este último há três condições capacitadoras que são relevantes para a busca da felicidade: recursos materiais, segurança e amor próprio. Enfim, não se defende o combate à pobreza, mas sim a busca por uma inserção valorativa do indivíduo em um contexto urbano que lhe proporcione a infra-estrutura para o seu desenvolvimento pessoal e como ente de uma coletividade. ${ }^{20}$

Ao finalizar essa breve reflexão sobre possibilidades de encaminhar uma sustentabilidade regional, e observando-se o cenário de ocupação urbana do aglomerado que circunda Curitiba, reafirmam-se as palavras de Bucci (2003) quando diz que a periferia é antes de tudo um laboratório experimental para a cultura arquitetônica e urbanística contemporânea. Ou seja, considera-se importante nesse contexto e nesse momento que as intervenções urbanísticas e o desenho da cidade contribuam para a realização humana nos planos individual e social. A construção social do lugar é mais importante do que a construção de um cenário urbano material tido como modelo mas que não tenha referência com os conteúdos pessoais e da sociedade que ali se instalou. Havendo, como se observa na Região Metropolitana de Curitiba. a interferência do contexto da globalização competitiva, os processos não serão, talvez nunca, definitivos. Como nos lembra Rykwert (2004), " a cidade não pode nunca ser uma organização formal estática”.

Primeiramente, as políticas de expansão urbana têm de levar em conta a conservação dos recursos naturais e especialmente para a RMC, da água. Partindo-se do pressuposto de que os recursos naturais estejam assegurados para o futuro, coloca-se na seqüência uma das raízes da sustenta-bilidade certamente centrada nas condições econômicas, emuma sociedade subordinada a uma economia global. Pelos estudos dos economistas sabe-se que a economia global insere espaços transnacionais de mão-de-obra de baixo custo sem, necessariamente, aumentar-lhes a renda,

20 Afirmação também baseada em resultados de pesquisas relatados em Meadows, D. et al. (1973), que mostram que nas populações de alguns contextos de pobreza dos países periféricos foram registrados índices mais altos de satisfação por pertencer a um grupo comunitário, maior sentimento de ser amado pela família e outros valores fundamentais para o bem-estar humano, em contraposição aos índices encontrados em pesquisas similares realizadas em comunidades de alta renda dos países centrais. 
LIMA, C. de A. Multiespacialidades metropolitanas e construção social do lugar...

como afirmaDupas (1999). Nesse sentido pode ser adequado adotar as diretrizes como apontou o Ministério do Meio Ambiente (1999) ${ }^{21}$ para definição de estratégias para a sustenta-bilidade baseada na função social da propriedade, segundo o Estatuto da Cidade, e reforçando as políticas apoiadas em ações de associação de cidadãos, conselhos de desenvolvimento local, fóruns de planejamento e deci-

\section{REFERÊNCIAS}

ACIOLY, C.; DAVIDSON, F. Densidade urbana. Rio de Janeiro: Mauad, 1998.

ACSELRAD, H. (Org.). A duração das cidades. Rio de Janeiro: DP\&A, 2001.

ACSELRAD, H. Discursos da sustentabilidade urbana. Revista brasileira de estudos urbanos e regionais. Campinas, $\mathrm{n}$. 1, p. 79-90, maio 1999.

BEZERRA, M. do C. de L; FERNANDES, M. A. (Coord.). Cidades sustentáveis. Brasília: Ministério do Meio Ambiente; Instituto de Administração Municipal, 2000.

BUCCI, F. Periferie e nuova urbanità. Milão: Electa, 2003.

COMEC. Proposta para área de interesse social - AISO Guarituba/Piraquara. Curitiba, 1999.

COMISSÃO MUNDIAL SOBRE MEIO AMBIENTE E DESENVOLVIMENTO. Nosso futuro comum. Rio de Janeiro: Fundação Getúlio Vargas, 1991.

CAMPANA, F. Curitiba pelos ingleses. Gazeta do Povo. Curitiba, jul. 2004, p. 8.

DEUS, Sérgio Luis de. Boas intenções não são suficientes. Gazeta do Povo. Curitiba, 11 jun. 2004, p. 10.

DUPAS, G. Economia global e exclusão social. São Paulo: Paz e Terra, 1999.

EGLER, C. In: IBGE. Brasil em números. IBGE. Centro de Documentação e Disseminação de informações, v.1. Rio de Janeiro, 2002.

IBGE. Censo demográfico 1991. Rio de Janeiro.

IBGE. Contagem populacional 1996. Rio de Janeiro.

IBGE. Censo populacional 2000. Rio de Janeiro.

IPARDES. Caracterização das regiões metropolitanas são que as reforcem e apóiem. Nesse sentido, entende-se como um dos melhores investimentos do poder público o desenvolvimento humano - tanto individual quanto coletivo - especialmente voltado para o empreendedorismo e para a inovação. A qualidade da organização socioambiental e a capacidade de inovação das comunidades são condicionantes para o desenvolvimento. institucionalizadas. Região Sul. Versão Preliminar. Convênio Ipea/IBGE/Unicamp/Ipardes, ago. 1999.

INSTITUTO DE PESQUISA E PLANEJAMENTO URBANO DE CURITIBA. Curitiba - uma experiência de planejamento. Curitiba, Ippuc, 1996.

LIMA, C. de A. Considerações sobre ocupações irregulares e parcelamento urbano em áreas de mananciais da Região Metropolitana de Curitiba. Desenvolvimento e meio ambiente, Curitiba, UFPR, n. 3, p. 97-114, 2001.

LIMA, C. de A. A ocupação de área de mananciais na Região Metropolitana de Curitiba: do planejamento à gestão ambiental urbana-metropolitana. Curitiba, 2000. Tese (Doutorado em Meio Ambiente e Desenvolvimento) - Universidade Federal do Paraná.

LIMA, C. de A.; MENDONÇA, F. de A. Planejamento urbano-regional e crise ambiental: Região Metropolitana de Curitiba. São Paulo em perspectiva. São Paulo, v. 15, n. 1, p. 135-143, jan./mar. 2001.

MARTINS, Fernando. O problema vai para a prancheta. $G a-$ zeta do Povo. Curitiba, 30 ago. 2004. p. 9.

MEADOWS, D. et al. Limites do crescimento. São Paulo: Perspectiva, 1973.

RATTNER, H. In: ACSELRAD, H. (Org.). A duração das cidades. Rio de Janeiro: DP\&A, 2001, p. 11.

REGISTER, R. Ecocity Berkeley. Berkeley, California: North Atlantic Books, 1987.

RYKWERT, J. A sedução do lugar. São Paulo: Martins Fontes, 2004.

WIGLEY, M. A desconstrução do espaço. In: SCHNITMAN, D. F. Novos paradigmas, cultura e subjetividade. Porto Alegre: Artes Médicas, 1996.

21 Ver BEZERRA e FERNANDES (2000). 